\title{
Pepper Accession LS2341 Is Highly Resistant to Ralstonia solanacearum Strains from Japan
}

\author{
Yutaka Mimura ${ }^{1}$ and Masami Yoshikawa \\ Biotechnology Research Department, Kyoto Prefectural Agriculture, \\ Forestry and Fisheries Technology Research Center, 74 Oji, Kitainayazuma, \\ Seika-cho, Soraku-gun, Kyoto Pref. 619-0244, Japan \\ Masashi Hirai \\ Graduate School of Life and Environmental Sciences, Kyoto Prefectural \\ University, Soraku, Kyoto 619-0244, Japan
}

Additional index words. bacterial wilt, Capsicum annuum, biovar, strain, KP9547

\begin{abstract}
Bacterial wilt caused by Ralstonia solanacearum is one of the most serious diseases in pepper (Capsicum annuиm) crops in warm-temperate, subtropical, and tropical areas, including Japan. Resistant lines are a prerequisite for breeding resistant cultivars but are not well studied. Eight pepper accessions previously described as resistant to the pathogen were selected and inoculated with a highly virulent strain, KP9547. Among them, Malaysian accession LS2341 exhibited the highest resistance. Accession LS2341 was then challenged with 14 virulent strains collected from various areas in Japan. The strains cover biovars 2T, 3, and 4 and include isolates from the host plants of tomato, eggplant, and pepper. Results indicated that accession LS2341 had the highest level of resistance to all the strains of $R$. solanacearum examined. Therefore, accession LS2341 was confirmed as an appropriate source for the breeding of resistant cultivars of pepper in Japan and is a candidate for a potential source of resistance in other areas.
\end{abstract}

Bacterial wilt caused by Ralstonia solanacearum is a serious disease in a wide range of crops. The bacteria enter the plants from roots in the natural process of infection (Vasse et al., 1995). After a phase of intercellular growth, bacteria gain entry into the plant xylem. Once the bacteria enter the vascular system, they spread and grow with the secretion of large quantities of extracellular polysaccharides (Buddenhagen and Kelman, 1964). Finally, they impair water flow in the plant and result in browning of the xylem and lethal generalized wilting. Bacterial wilt of tomato and potato has been extensively studied. However, studies on bacterial wilt of pepper are rather limited. Bacterial wilt of pepper is known in tropical, subtropical, and warm-temperate zones in Asia, South America, Oceania, and Africa (Elphinstone, 2005), and the isolates virulent to pepper were reported in North America in 2006 (Ji et al., 2007). The disease is also widely observed in Japan (Horita and Tsuchiya, 2001; Iwamoto et al., 1988; Monma et al., 1993; Osaki and Kimura, 1992; Suzuki et al., 1964). Damage has been observed even in the pepper cultivars Fushimi-amanaga and Manganji, which were previously known as resistant (Hashimoto et al., 2001; Matsunaga

Received for publication 8 June 2009. Accepted for publication 29 Aug. 2009.

We thank A. Kato for statistical advice.

${ }^{1}$ To whom reprint requests should be addressed; e-maily-mimura02@pref.kyoto.lg.jp. and Monma, 1999; Tsuro et al., 2007). This suggests the occurrence of highly virulent strains in Japan. Hashimoto et al. made a survey of 81 isolates of the pathogen classified as biovars 3 or 4 in Kyoto, Japan, and found a highly virulent isolate, strain KP9547, from the pepper cultivar Fushimiamanaga (Hashimoto et al., 2001). Pepper lines resistant to bacterial wilt have been reported in several laboratories. Matos et al. found MC4 and MC5 to be resistant (Matos et al., 1990). MC4 was resistant to various isolates of biovar 1 and 3 and has been recommended for breeding programs in Brazil (Lopes et al., 2005; Quezado-Soares and Lopes, 1995). A resistant cultivar, MieMidori, and its progeny have been extensively used in the breeding of resistant cultivars (Matsunaga and Monma, 1999). In a preliminary report, a Malaysian accession, LS2341, was found to be resistant (Mimura et al., 2000). After screening 30 genotypes, two were found to be highly resistant to bacterial wilt in India (Singh and Sood, 2004). However, most of these tests were done using only one or two isolates of the pathogen (Fatima and Joseph, 2001; Matsunaga and Monma, 1999; Singh and Sood, 2004; Wang and Berke, 1997). Because the pathogen of bacterial wilt has a wide range of virulence, it is uncertain whether these resistant lines would be effective against various isolates collected from other regions.

This study was conducted to determine highly resistant line(s) suitable as a source of breeding materials by challenging possible candidates with a wide diversity of pathogens collected in Japan.

\section{Materials and Methods}

Capsicum accessions. Eight Capsicum annuum accessions, which are previously described as resistant to bacterial wilt, were used in this study, and are listed in Table 1 (Hashimoto et al., 2001; Matos et al., 1990; Matsunaga and Monma, 1999; Mimura et al., 2000; Quezado-Soares and Lopes, 1995; Tsuro et al., 2007). The bell-type sweet pepper, $C$. annuum cv. California Wonder, was included as a susceptible control for the pathogenicity test (Peter et al., 1984).

Bacterial strains and growth conditions. All $R$. solanacearum strains used in this study belong to race 1 and are listed in Table 2 . Strain KP9547 was isolated from naturally infected plants of the pepper cultivar, Fushimiamanaga, in Kyoto, Japan (Hashimoto et al., 2001). Fourteen additional strains belonging to biovars $2 \mathrm{~T}, 3$, and 4 were carefully selected to cover a wide variation of virulence of the pathogen in Japan. All strains were maintained as suspensions in sterile distilled water at $20{ }^{\circ} \mathrm{C}$. Cultures from these stocks were streaked on Kelman's tetrazolium chloride (TZC) agar medium and maintained at $30{ }^{\circ} \mathrm{C}$ for 36 to $48 \mathrm{~h}$, and a single fluidal colony of each strain was grown on the same medium without TZC (Kelman's broth) with reciprocal shaking $(180 \mathrm{rpm})$ at $30{ }^{\circ} \mathrm{C}$ for $48 \mathrm{~h}$ (Kelman, 1954).

Pathogenicity test. Bacterial cells grown as described previously were collected by centrifugation at $10,000 \mathrm{~g}$ for $20 \mathrm{~min}$ and then resuspended in sterile distilled water $\left(4 \times 10^{8}\right.$ colony-forming units $/ \mathrm{mL}$ ). Infested soil was prepared by pouring $2 \mathrm{~mL}$ of the bacterial suspension into a planting hole made at the center of a 9-cm diameter plastic pot containing $200 \mathrm{~mL}$ of a granulating soil (NippiEngei-Baido-1gou; Nihon Hiryo Co., Tokyo, Japan). The soil is composed of $65 \%$ of volcanic soil, $35 \%$ of humus, and contained $200 \mathrm{mg} \cdot \mathrm{L}^{-1}$ nitrogen, $2500 \mathrm{mg} \cdot \mathrm{L}^{-1}$ phosphorus, $200 \mathrm{mg} \cdot \mathrm{L}^{-1}$ potassium, and $200 \mathrm{mg} \cdot \mathrm{L}^{-1}$ magnesium. The soil $\mathrm{pH}$ was adjusted between 5.8 and 6.5. Four-week-old seedlings at the third true leaf stage, which were grown with sterilized vermiculite, were then transplanted into the planting hole (one plant/pot). The plots of accessions and/or strains were arranged in a randomized complete block design and four replications of six plants were used for each plot. Each pot was watered separately once in $2 \mathrm{~d}$ during the tests. These seedlings were grown for 4 weeks and observed wilting symptoms for 6 weeks in a greenhouse at temperatures between 20 and $37^{\circ} \mathrm{C}$. The greenhouse was ventilated when the temperature rose to 25 and $30{ }^{\circ} \mathrm{C}$ during seedling growing and symptom observing period, respectively.

Disease evaluation and data analysis. To score wilting, plants having at least one wilted leaf were classified as wilted. The proportion of wilted plants (PW) was scored at weekly intervals for 6 weeks. Statistical 
Table 1. Pepper accessions tested for resistance to bacterial wilt and their characteristics.

\begin{tabular}{|c|c|c|c|c|c|c|}
\hline Accession or cultivar & Origin & Obtained from & Fruit shape & Pungency & Phenotype & Reference \\
\hline LS2341 & Malaysia & $\mathrm{MAFF}^{\mathrm{z}}$ & Small New-mex & Hot & Resistance & Mimura et al., 2000 \\
\hline Manganji & Kyoto, Japan & $\mathrm{KAB}^{\mathrm{y}}$ & New-mex & Sweet & Resistance & Tsuro et al., 2007 \\
\hline Fushimi-amanaga & Kyoto, Japan & KAB & Cayenne & Sweet & Resistance & Hashimoto et al., 2001 \\
\hline Mie-midori & Mie, Japan & MAFF & Small Bell & Sweet & Resistance & Matsunaga and Monma, 1999 \\
\hline Ishii-midori & Hyogo, Japan & MAFF & Small Bell & Sweet & Resistance & Matsunaga and Monma, 1999 \\
\hline Akashi & Hyogo, Japan & MAFF & Small Bell & Sweet & Resistance & Matsunaga and Monma, 1999 \\
\hline $\mathrm{MC} 4$ & Malaysia & MAFF & Small & Hot & Resistance & Quezado-Soares and Lopes, 1995 \\
\hline MC5 & Malaysia & MAFF & Small & Hot & Resistance & Matos et al., 1990 \\
\hline California Wonder & USA & MAFF & Bell & Sweet & Susceptible & Peter et al., 1984 \\
\hline
\end{tabular}

${ }^{2}$ MAFF $=$ Ministry of Agriculture, Forestry, and Fisheries Genebank, National Institute of Agrobiological Sciences, Tsukuba, Japan.

${ }^{\mathrm{y}} \mathrm{KAB}=$ Kyoto Prefectural Institute of Agricultural Biotechnology Genebank, Seika, Kyoto, Japan.

Table 2. Strains of Ralstonia solanacearum used resistance testing and their host plant, origin, and classification.

\begin{tabular}{|c|c|c|c|c|c|c|}
\hline Strain & Host plant & $\begin{array}{c}\text { Geographical } \\
\text { origin }\end{array}$ & Race & Biovar & Phylotype & $\begin{array}{l}\text { Obtained } \\
\text { from }\end{array}$ \\
\hline KP9547 & Capsicum annuum & Kyoto, Japan & 1 & 4 & I & $\mathrm{KAB}^{\mathrm{z}}$ \\
\hline MAFF106605 & Solanum lycopersicum & Kumamoto, Japan & 1 & $2 \mathrm{~T}$ & I & $\mathrm{MAFF}^{\mathrm{y}}$ \\
\hline MAFF211266 & Solanum lycopersicum & Hiroshima, Japan & 1 & 4 & I & MAFF \\
\hline MAFF211267 & Solanum lycopersicum & Shimane, Japan & 1 & 4 & I & MAFF \\
\hline MAFF211268 & Solanum melongena & Kochi, Japan & 1 & 4 & I & MAFF \\
\hline MAFF211269 & Solanum melongena & Kochi, Japan & 1 & 4 & I & MAFF \\
\hline MAFF2 11270 & Solanum lycopersicum & Shizuoka, Japan & 1 & $2 \mathrm{~T}$ & I & MAFF \\
\hline MAFF 211280 & Solanum melongena & Kochi, Japan & 1 & $2 \mathrm{~T}$ & I & MAFF \\
\hline MAFF211282 & Solanum melongena & Kochi, Japan & 1 & 3 & I & MAFF \\
\hline MAFF211500 & Solanum melongena & Kochi, Japan & 1 & 3 & I & MAFF \\
\hline MAFF211514 & Solanum lycopersicum & Kochi, Japan & 1 & 3 & I & MAFF \\
\hline MAFF301487 & Solanum lycopersicum & Oita, Japan & 1 & $2 \mathrm{~T}$ & I & MAFF \\
\hline MAFF730129 & Solanum melongena & Kochi, Japan & 1 & 4 & I & MAFF \\
\hline KAMI 1-1 & Capsicum аппиит & Kochi, Japan & 1 & 4 & I & KARC $^{\mathrm{x}}$ \\
\hline KITAHAN 1-4 & Capsicum аппиит & Kochi, Japan & 1 & 4 & I & KARC \\
\hline
\end{tabular}

${ }^{2} \mathrm{KAB}=$ Kyoto Prefectural Institute of Agricultural Biotechnology Genebank, Seika, Kyoto, Japan.

${ }^{\mathrm{y}} \mathrm{MAFF}=$ Ministry of Agriculture, Forestry, and Fisheries Genebank, National Institute of Agrobiological Sciences, Tsukuba, Japan.

${ }^{\mathrm{x}}$ KARC $=$ Kochi Prefectural Agricultural Research Center Genebank, Nangoku, Kochi, Japan.

Table 3. Proportion of wilted plants of the nine pepper accessions during 6 weeks after inoculation with the Japanese highly virulent KP9547 strain of Ralstonia solanacearum.

\begin{tabular}{lcccccc}
\hline & \multicolumn{6}{c}{ Proportion of wilted plant $(\%)^{\mathrm{z}}$} \\
\cline { 2 - 7 } Accession or cultivar & $1 \mathrm{WAI}^{\mathrm{y}}$ & $2 \mathrm{WAI}$ & $3 \mathrm{WAI}$ & $4 \mathrm{WAI}$ & $5 \mathrm{WAI}$ & $6 \mathrm{WAI}$ \\
\hline LS2341 & 0 & 0 & 4 & 4 & 4 & 4 \\
Manganji & $25^{*}$ & $79^{* * *}$ & $96^{* * *}$ & $96^{* * *}$ & $96^{* * *}$ & $96^{* * *}$ \\
Fushimi-amanaga & 4 & $29^{* *}$ & $38^{* *}$ & $42^{* *}$ & $46^{* * *}$ & $50^{* * *}$ \\
Mie-midori & 8 & $42^{* * *}$ & $58^{* * *}$ & $63^{* * *}$ & $63^{* * *}$ & $67^{* * *}$ \\
Ishii-midori & 4 & $42^{* * *}$ & $46^{* * *}$ & $58^{* * *}$ & $54^{* * *}$ & $63^{* * *}$ \\
Akashi & 17 & $58^{* * *}$ & $63^{* * *}$ & $71^{* * *}$ & $71^{* * *}$ & $71^{* * *}$ \\
MC4 & 0 & 17 & $38^{* *}$ & $38^{* *}$ & $46^{* * *}$ & $46^{* * *}$ \\
MC5 & $21^{* *}$ & $42^{* * *}$ & $58^{* * *}$ & $63^{* * *}$ & $63^{* * *}$ & $63^{* * *}$ \\
California Wonder & $79^{* * *}$ & $100^{* * *}$ & $100^{* * *}$ & $100^{* * *}$ & $100^{* * *}$ & $100^{* * *}$ \\
\hline
\end{tabular}

${ }^{2}$ Proportion of wilted plants represents the means of four replications with six plants each. Significance: different from the one of resistant accession LS2341 according to the $\chi^{2}$ test for independence or Fisher's exact probability test.

${ }^{\mathrm{y}} \mathrm{WAI}=$ week $(\mathrm{s})$ after inoculation.

*, **, ***Significant at $P \leq 0.05,0.01,0.001$, respectively.

significance of differences was tested using the $\chi^{2}$ test for independence or Fisher's exact probability test.

\section{Results and Discussion}

The inoculation resulted in rapid wilting symptoms in the susceptible control, 'California Wonder', and all plants were wilted at 2 weeks after inoculation (WAI). The symptoms progressed to death with tissue collapse in all control plants tested. Similarly, rapid wilting was observed in Manganji with a PW of $79 \%$ at 2 WAI, reaching $96 \%$ at 6 WAI.
In contrast, Malaysian accession LS2341 showed no wilting symptoms at 2 WAI, reaching only $4 \%$ at 6 WAI. Seven accessions, including Manganji, already showed substantial increases in PW at 2 WAI, whereas the PW of MC4 was not significantly different from that of LS2341 at that time. However, the wilting of MC4 rapidly increased at 3 WAI. These results showed that of all the accessions used in this study, Malaysian accession LS2341 was the most resistant to KP9547 (Table 3). Before this experiment, the same set of eight pepper accessions were inoculated with KP9547 in two preliminary experiments. LS2341 showed the highest resistance among the eight accessions in both experiments like in the present study (Mimura et al., 2008a). These results indicate that LS2341 constantly showed the highest resistance to KP9547.

Then, LS2341 was inoculated with 14 strains of the pathogen. This accession showed high resistance to all 14 strains collected from tomato, eggplant, and pepper from different locations in Japan (Table 4). These included biovars 2T, 3, and 4. Only one strain caused slight wilting of LS2341. In contrast, all of the inoculated strains caused severe wilting in the susceptible control, 'California Wonder', the severity of which varied substantially among the strains at 3 WAI. Strain KP9547 caused the highest degree of wilting at $3 \mathrm{WAI}$, reaching $100 \%$ wilting at $6 \mathrm{WAI}$, and is considered the most virulent of the 14 isolates tested (Table 4). In a preliminary experiment, accession LS2341 was inoculated with 12 virulent $R$. solanacearum, which were also used in this study. All strains caused almost no wilting in LS2341 at 6 WAI (Mimura et al., 2008a).

Screening for plant resistance to bacterial wilt has been reported in several laboratories, where resistance was evaluated using different $R$. solanacearum strains and different inoculation methods. For this reason, direct comparison of the degree of resistance was difficult. In this study, we selected eight pepper accessions previously reported as highly resistant to bacterial wilt and compared their resistance using KP9547, which is highly virulent to pepper of the Japanese isolates (Hashimoto et al., 2001). The results indicate that accession LS2341 has a high level of resistance to virulent strains of $R$. solanacearum in Japan.

The pathogen $R$. solanacearum is a highly diverse species and is classified into five races based on host range and six biovars based on use of carbon sources (Hayward, 1991). Recently, DNA-based analysis has become popular for understanding phylogenic relationships among $R$. solanacearum strains (Fegan and Prior, 2005). Therefore, it is essential to determine the resistance profile of accessions against a wide range of pathogen isolates before the breeding of resistant cultivars starts. Strains in races 3 and 4 that are pathogenic to potato and ginger, respectively (Horita and Tsuchiya, 2002), also have been reported in Japan. Since strains from races 3 or 4 from Japan caused no or only 
Table 4. Proportion of wilted plants of the accession LS2341 and cultivar California Wonder inoculated with virulent Japanese strains of Ralstonia solanacearum.

\begin{tabular}{|c|c|c|c|c|c|}
\hline \multirow{2}{*}{\multicolumn{2}{|c|}{ Strain inoculated }} & \multicolumn{4}{|c|}{ Proportion of wilted plant $(\%)^{2}$} \\
\hline & & \multicolumn{2}{|c|}{ LS2341 } & \multicolumn{2}{|c|}{ California Wonder } \\
\hline Strain & Host plant & $3 \mathrm{WAI}^{\mathrm{y}}$ & $6 \mathrm{WAI}$ & 3 WAI & $6 \mathrm{WAI}$ \\
\hline KP9547 (positive control) & Pepper & 0 & 0 & 75 & 100 \\
\hline MAFF106605 & Tomato & 0 & 0 & 42 & 75 \\
\hline MAFF211266 & Tomato & 0 & 0 & 21 & 92 \\
\hline MAFF211267 & Tomato & 0 & 0 & 38 & 88 \\
\hline MAFF211268 & Eggplant & 0 & 0 & 17 & 96 \\
\hline MAFF211269 & Eggplant & 0 & 0 & 58 & 96 \\
\hline MAFF211270 & Tomato & 0 & 0 & 38 & 79 \\
\hline MAFF211280 & Eggplant & 0 & 8 & 25 & 83 \\
\hline MAFF211282 & Eggplant & 0 & 0 & 38 & 79 \\
\hline MAFF211500 & Eggplant & 0 & 0 & 8 & 79 \\
\hline MAFF211514 & Tomato & 0 & 0 & 25 & 63 \\
\hline MAFF301487 & Tomato & 0 & 0 & 21 & 88 \\
\hline MAFF730129 & Eggplant & 0 & 0 & 29 & 71 \\
\hline KAMI 1-1 & Pepper & 0 & 0 & 25 & 83 \\
\hline KITAHAN 1-4 & Pepper & 0 & 0 & 25 & 88 \\
\hline \multicolumn{2}{|c|}{ Noninoculated control } & 0 & 0 & 0 & 0 \\
\hline
\end{tabular}

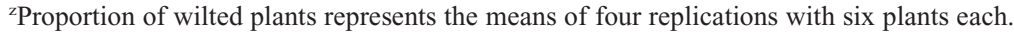
${ }^{\mathrm{y}} \mathrm{WAI}=$ weeks after inoculation.

slight wilting in 'California Wonder' (Mimura et al., 2008b), they were excluded from the present study. Therefore, the present study is thought to cover representatives of the virulent strains of $R$. solanacearum found in Japan. LS2341 showed a high level of resistance and would be an appropriate source for breeding resistant pepper cultivars. It may also be useful as a standard for pepper lines highly resistant to bacterial wilt in future pathological studies. Because this study was conducted using pathogen isolates collected only in Japan, isolates from other areas may produce different results. However, LS2341 would be a candidate of the most resistant of the peppers among the accessions previously reported as resistant.

Previous studies showed that most resistant pepper lines originated in Asia, especially in Southeast Asia (Matsunaga and Monma, 1999; Wang and Berke, 1997). Moreover, we found a highly resistant line among Malaysian accessions. Although a detailed study has not been published, it is well known that bacterial wilt is widely observed in Southeast Asia and is a serious problem in the cultivation of pepper crops, which are extensively cultivated and used as spices and vegetables. As such, cultivars in this area may receive high selection pressure toward resistance to bacterial wilt. Although pepper species originated in South America, where they exhibit wide genetic variation (Debouck and LibrerosFerla, 1996; Eshbaugh et al., 1983; McLeod et al., 1982), Southeast Asia may be an important area as a source of pepper germplasm resistant to bacterial wilt.

\section{Literature Cited}

Buddenhagen, I.W. and A. Kelman. 1964. Biological and physiological aspects of bacterial wilt caused by Pseudomonas solanacearum. Annu. Rev. Phytopathol. 2:203-230.

Debouck, D.G. and D. Libreros Ferla. 1996. Spicy sauce, or a brief history of the pepper (Capsicum) in Colombia [in Spanish]. p. 1-18. In: Proceed- ings of the 5th Meeting on Promising Plant Resources. National University of Colombia at Palmira.

Elphinstone, J.G. 2005. The current bacterial wilt situation: A global view, p. 9-28. In: Allen, C., P. Prior, and C. Hayward (eds.). Bacterial wilt disease and the Ralstonia solanacearum species complex. APS Press, St. Paul, MN.

Eshbaugh, W.H., S.I. Guttman, and M.J. McLeod. 1983. The origin and evolution of domesticated Capsicum species. Ethnobiology 3:49-54.

Fatima, A.G. and S. Joseph. 2001. Reaction of different chili (Capsicum annuum) genotypes to bacterial wilt. Capsicum \& Eggplant Newsletter 20:82-85.

Fegan, M. and P. Prior. 2005. How complex is the "Ralstonia solanacearum species complex"? p. 449-461. In: Allen, C., P. Prior, and C. Hayward (eds.). Bacterial wilt disease and the Ralstonia solanacearum species complex. APS Press, St. Paul, MN.

Hashimoto, N., S. Matsumoto, M. Yoshikawa, M. Horita, and K. Tsuchiya. 2001. Varietal resistance among red pepper and sweet pepper cultivars to Ralstonia solanacearum isolated in Kyoto Prefecture [abstract in Japanese]. Jpn. J. Phytopathol. 67:201-202.

Hayward, A.C. 1991. Biology and epidemiology of bacterial wilt caused by Pseudomonas solanacearum. Annu. Rev. Phytopathol. 29:65-87.

Horita, M. and K. Tsuchiya. 2001. Genetic diversity of Japanese strains of Ralstonia solanacearum. Phytopathology 91:399-407.

Horita, M. and K. Tsuchiya. 2002. The strain of preservation bacterial wilt registered in MAFF [in Japanese]. In: MAFF microorganism genetic resources manual No.12 causal agent of bacterial wilt disease Ralstonia solanacearum. National Institute of Agrobiological Sciences, Tsukuba, Japan.

Iwamoto, M., Y. Ikeuchi, T. Kobayashi, M. Takegawa, N. Tanaka, and Y. Yamamoto. 1988. Studies on the establishment of agronomical protection against soil-borne diseases of green peppers [in Japanese with English summary]. Bull. Hyogo Pref. Agr. Inst. 36:23-28.

Ji, P., C. Allen, A. Sanchez-Perez, J. Yao, J.G. Elphinstone, J.B. Jones, and M.T. Momol. 2007. New diversity of Ralstonia solanacearum strains associated with vegetable and ornamental crops in Florida. Plant Dis. 91:195-203.
Kelman, A. 1954. The relationship of pathogenicity in Pseudomonas solanacearum to colony appearance on tetrazolium medium. Phytopathology 44:693-695.

Lopes, C.A., S.I.C. Carvalho, and L.S. Boiteux. 2005. Search for resistance to bacterial wilt in a Brazilian Capsicum germplasm collection, p. 247-251. In: Allen, C., P. Prior, and C. Hayward (eds.). Bacterial wilt disease and the Ralstonia solanacearum species complex. APS Press, St. Paul, MN.

Matos, F.S.A., C.A. Lopes, and A. Takatsu. 1990. Identificação de fonts de resistência a Pseudomonas solanacearum en Capsicum spp. Horticultura Brasileira 8:22-23.

Matsunaga, H. and S. Monma. 1999. Sources of resistance to bacterial wilt in Capsicum. J. Jpn. Soc. Hort. Sci. 68:753-761.

McLeod, M.J., S.I. Guttman, and W.H. Eshbaugh 1982. Early evolution of chili peppers (Capsicum). Econ. Bot. 36:361-368.

Mimura, Y., H. Matsunaga, T. Yoshida, and T. Sato. 2000. Pathogenicity of various isolates of Ralstonia solanacearum on tomato, eggplant and pepper varieties [abstract in Japanese]. J. Jpn. Soc. Hort. Sci. 69(suppl 1):231.

Mimura, Y., M. Yoshikawa, and M. Hirai. 2008a. Property of resistance to bacterial wilt in Capsicum line 'LS2341' [abstract in Japanese]. Hort. Res. Japan 7(suppl 1):100.

Mimura, Y., M. Yoshikawa, and M. Hirai. 2008b. Evaluation of resistance to bacterial wilt in Capsicum cultivar 'Kyoto-Manganji-1gou' [abstract in Japanese]. Hort. Res. Japan 7(suppl 2):177.

Monma, S., T. Narikawa, Y. Sakata, and K. Hida. 1993. Resistance to bacterial wilt in tomato cultivars [in Japanese with English summary]. Bull. Natl. Res. Inst. Veg. Ornam. Plants and Tea. A6:1-12.

Osaki, K. and T. Kimura. 1992. Grouping of Pseudomonas solanacearum on the basis of pathogenicity to Solanum plants [in Japanese with English summary]. Bull. Chugoku Natl. Agr. Exp. Stn. 10:49-58.

Peter, K.V., R.W. Goth, and R.E. Webb. 1984. Indian hot peppers as new sources of resistance to bacterial wilt, Phytophthora root rot and root rot nematodes. HortScience 19:277-278.

Quezado-Soares, A.M. and C.A. Lopes. 1995. Stability of the resistance to bacterial wilt of the sweet pepper 'MC-4' challenged with strains of Pseudomonas solanacearum. Fitopatol. Bras. 20:638-641.

Singh, Y. and S. Sood. 2004. Screening of sweet pepper germplasm for resistance to bacterial wilt (Ralstonia solanacearum). Capsicum \& Eggplant Newsletter 23:121-124.

Suzuki, I., Y. Sugahara, A. Kotani, S. Todaka, and H. Shimada. 1964. Studies on breeding eggplants and tomatoes for resistance to bacterial wilt. I. Investigations on method of evaluating the resistance and on the source of resistance in eggplants and tomatoes [in Japanese with English summary]. Bull. Hort. Res. Stn., Japan. Ser. A 3:77-106.

Tsuro, M., Y. Minamiyama, and M. Hirai. 2007. QTL analysis for bacterial wilt resistance in Japanese pepper (Capsicum annuum L.) [in Japanese]. Breeding Research. 9:111-115.

Vasse, J., P. Frey, and A. Trigalet. 1995. Microscopic studies of intercellular infection and protoxylem invasion of tomato roots by $\mathrm{Pseu}$ domonas solanacearum. Mol. Plant Microbe Interact. 8:241-251.

Wang, J.F. and T. Berke. 1997. Sources of resistance to bacterial wilt in Capsicum annuum. Capsicum \& Eggplant News Letter 16:91-93. 